\title{
Systematic review of Energy Efficiency (E.E.). Basis for an alternative vision of E.E. in Colombia
}

\author{
Revisión sistemática de Eficiencia Energética (E.E.). Bases para una visión \\ alternativa de E.E. en Colombia
}

C. Méndez-Rodríguez iD ; C.F. Rengifo-Rodas iD; J.C. Corrales-Muñoz iD; A. Figueroa-Casas iD

\begin{abstract}
The management of natural resources, especially energy resources, is a challenge for today's society. For this reason, Energy Efficiency (E.E.) is considered as a key tool to promote economic growth, reduce the consumption of natural energy resources, and help to solve multiple environmental impacts. In this study, a systematic mapping of the literature concerning E.E. is carried out. Based on the research questions formulated in the systematic mapping, a knowledge gap is identified, which is that the problems linked to energy are not being addressed from a systemic and interdisciplinary paradigm. This calls for the development of methodological, sociological, and technological processes that allow understanding of E.E. from a systemic perspective. Finally, the basis for an alternative vision of E.E. in Colombia is proposed, which tends towards the sustainability and conservation of natural energy resources.
\end{abstract}

Index Terms - energy, Energy Efficiency (E.E.), sustainability, interdisciplinary, systemic

Resumen- La gestión de los recursos naturales, en especial los energéticos, constituyen un desafío para la sociedad actual. Por esta razón, la Eficiencia Energética (E.E.) es considerada como una herramienta clave para promover el crecimiento económico, reducir el consumo de recursos naturales energéticos $\mathbf{y}$ ayudar a dar solución a múltiples impactos ambientales. En este estudio es realizado un mapeo sistemático de la literatura concerniente a la Eficiencia Energética (E.E.). A partir de las preguntas de investigación formuladas en el mapeo sistemático es identificada 2020

This manuscript was sent on August 20, 2019 and accepted on March 28,

This document is part of a doctoral thesis in Environmental Sciences funded by Colciencias through the program for National Doctorates. Special recognition is given to Colciencias and to the University of Cauca.

C. Méndez-Rodríguez, (c) PhD in Environmental Sciences, University of Cauca, Popayán, Colombia (e-mail: cristianmendez@unicauca.edu.co)

C.F. Rengifo-Rodas, Professor, Department of Electronics, Instrumentation and Control, University of Cauca, Popayán, Colombia (e-mail: caferen@unicauca.edu.co)

J.C. Corrales-Muñoz, Professor, Department of Telematics, University of Cauca, Popayán, Colombia (e-mail: jcorral@unicauca.edu.co)

A. Figueroa-Casas, Professor, Department of Biology, University of Cauca, Popayán, Colombia (e-mail: apolinar@unicauca.edu.co) una brecha de conocimiento, la cual está orientada a abordar las problemáticas ligadas a la energía desde un paradigma sistémico, e interdisciplinar. Esto implica el desarrollo de procesos metodológicos, sociológicos y tecnológicos que permitan entender la E.E. desde una perspectiva sistémica. Finalmente, son propuestas las bases de una visión alternativa de E.E. en Colombia que propende por la sustentabilidad y la conservación de los recursos naturales energéticos.

Palabras claves - energía, Eficiencia Energética (E.E.), sustentabilidad, interdisciplinariedad, sistémico.

\section{INTRODUCTION}

$\mathrm{T}$ HE use and exploitation of energy resources is not exclusive to modern economies. Since ancient times, man has been known to use sources of energy other than his own physical force (endosomatic energy), such as: the work of domestic animals to obtain mechanical energy, the force of the wind, the currents of water as generators of movement, and the heat obtained by the combustion of wood [1]. Some time later, coal, hydrocarbons, and hydroelectricity began to be used, and now gas and nuclear energy are being used; all of which play essential roles for social development and industrialization [2].

By the beginning of the 21 st century, energy consumption had doubled in comparison to the last three decades of the last century [2]. Due to this change, meeting the energy demands of the modern man has become an urgent challenge for humanity. At this point, the demands of society have exceeded the planets ability to produce the resources we need and to absorb the waste we produce [3]. This has led to the awareness of our need to reorient the production and use of energy resources by giving more importance to the use of renewable energies, by promoting the rational use of energy sources, and by seeking alternatives for E.E. All with the aim of making the existence of the human species on this planet sustainable.

The conversion and use of different sources of energy generates problems and impacts on natural systems, such as: climate change, the depletion of fossil fuels, GHG 
(Greenhouse Gases) emissions, air pollution, heat islands, and the consumption of water resources [4]. In this regard, to address energy concepts and E.E. it is necessary to remember the two fundamental principles of thermodynamics [5]: Energy is subject to the principle of conservation but also to a law that recognizes its qualitative and irreversible degradation [6]. From the modern scientific praxis, the unlimited possibilities of energy transformation emerge from the first law of thermodynamics, which constitutes the fundamental foundation of "progress". Nevertheless, not enough attention is paid to the principle of entropy, leading to "ignorance" of the finite condition of energy resources [7].

The objective of this study is to make a systematic map of literature, emphasizing the advances and contributions of diverse studies in the field of E.E. Equally, another purpose is to find the knowledge gaps that have not yet been addressed, which can lead to a comprehension and application of E.E. from a sustainable viewpoint. A knowledge gap identified in this study is the necessity of approaching problems tied to energy from a systemic and interdisciplinary paradigm. With that in mind, we propose a systemic vision of E.E. One that constructs a concept of E.E. based on the conceptual triangulation of three disciplines and that makes an analysis of the hierarchical levels of society to evaluate E.E.

To address the aforementioned topic, this paper is structured as follows: section 2 describes the research method used to construct the systematic mapping; Section 3 presents the results of the systematic mapping and the identification of gaps; the discussion and the bases for an alternative vision of E.E. in Colombia are also addressed in section 4; finally, in section 5 the conclusions are presented.

\section{MethodS - Systematic MAPPING}

To establish a starting point in regard to the knowledge generated in the field of E.E. this paper uses the systematic mapping technique proposed in [8], which proposes a procedure consisting of 5 stages (see Fig. 1). The application of this technique allows for a deeper understanding in the subject of E.E., sorting published research into categories and

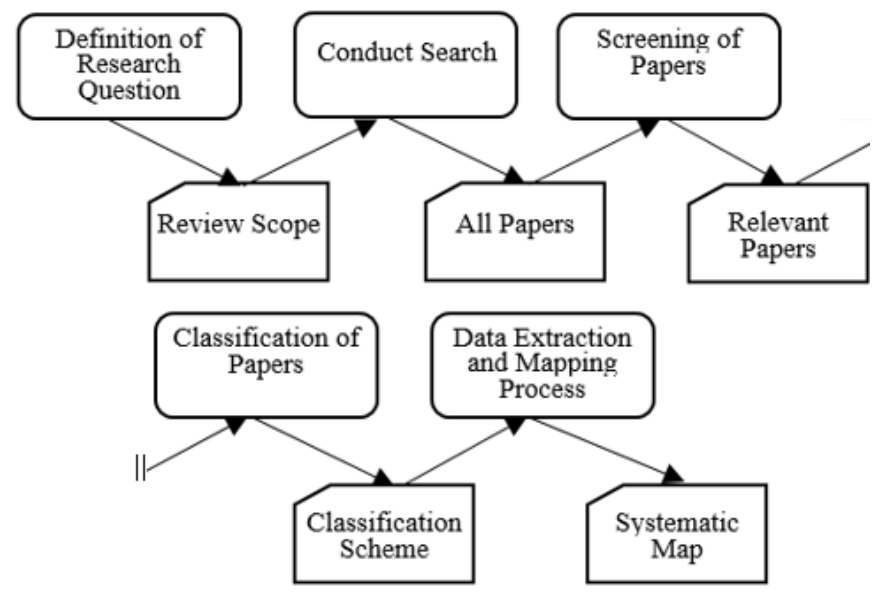

Fig. 1. The systematic mapping process. finding knowledge gaps that have not yet been addressed. Next, the 5 stages for carrying out the systematic mapping are described.

\section{A. Definition of Research Question}

The main objectives of this study are to become familiar with the research that has been conducted concerning E.E., to see the main contributions these works have had, and to gain an understanding of what the trends are in new research. To obtain a comprehensive view of the subject, the following three research questions (RQ) are posed:

- RQ.1. What topics interest the scientific community regarding E.E. on a time scale of the last 12 years?

- RQ.2. What are the main contributions of research on E.E.?

- RQ.3. What are alternatives that have not yet been explored in full and that can provide an understanding and application of E.E. from a sustainable viewpoint?

\section{B. Conduct Search}

The 5 databases used to conduct the search were established based on the importance of each one within the scientific community on an international level; those being: IEEE Xplore, Science Direct, Springer, Ebsco, and Google Scholar. The six search chains used were: "energy efficiency" (E.E.), "energy efficiency models", "energy efficiency AND sustainability", "energy efficiency AND environmental impact (EI)", "socio-ecological systems (SES) AND energy", and "socio-ecological systems (SES) AND energy efficiency". The search was done in English, Spanish, and French, taking into account studies from 2006 onwards, resulting in 500 scientific texts.

\section{Screening of Papers}

Within the process of selecting studies, two criteria were established to determine their relevance: i) Inclusion: works that address the subject of E.E. and/or energy management, which contemplate relationships between at least two of the following socio-ecological dimensions: political, economic, cultural, technological, educational. ii) Exclusion: studies in E.E. and/or energy management that propose exclusively technical - technological solutions, without considering social, environmental, or economic impacts. Applying these criteria, 201 scientific papers were obtained (see Table 1).

The search chains that relate E.E. to sustainability and environmental impact and those that relate energy to SES offer the greatest precision, that is to say, the works found with these chains are those that are most relevant for this mapping study.

\section{Classification of Papers}

The 201 selected studies were analyzed in greater depth with the aim of classifying them into three facets (see Fig. 2): i) Thematic facet: contains the search chains, ii) Research facet: 
TABLE I

SEARCH RESULT: STUDIES FOUND BY EACH SEARCH STRING IN THE

\begin{tabular}{|c|c|c|c|c|c|c|c|c|}
\hline \multirow[t]{2}{*}{$\begin{array}{c}\text { SEARCH } \\
\text { CHAIN }\end{array}$} & \multirow[t]{2}{*}{ \# S-F } & \multicolumn{5}{|c|}{$\begin{array}{c}\text { SELECTED STUDIES BY } \\
\text { DATABASE }\end{array}$} & \multirow[t]{2}{*}{$\begin{array}{c}\# \\
\text { S-S }\end{array}$} & \multirow[t]{2}{*}{$\begin{array}{c}\text { PR } \\
\%\end{array}$} \\
\hline & & IEEE & $\mathrm{SC}$ & SP & EB & GS & & \\
\hline E.E. & 297 & 8 & 76 & 4 & 7 & 4 & 99 & 33 \\
\hline E.E. models & 123 & 9 & 29 & 6 & 4 & & 48 & 39 \\
\hline $\begin{array}{l}\text { E.E. AND } \\
\text { sustainability }\end{array}$ & 63 & 5 & 17 & 11 & 2 & 2 & 37 & 59 \\
\hline $\begin{array}{l}\text { E.E. AND } \\
\text { environm. } \\
\text { Impact }\end{array}$ & 15 & 4 & 11 & 0 & 0 & 0 & 15 & 100 \\
\hline $\begin{array}{c}\text { SES AND } \\
\text { energy }\end{array}$ & 2 & 0 & 0 & 0 & 0 & 2 & 2 & 100 \\
\hline $\begin{array}{l}\text { SES AND } \\
\text { E.E. }\end{array}$ & 0 & 0 & 0 & 0 & 0 & 0 & 0 & - \\
\hline TOTAL & 500 & 26 & 133 & 21 & 13 & 8 & 201 & \\
\hline
\end{tabular}

\# S-F: \# STUDIES FOUND

SC: SCIENCE DIRECT

EB: EBSCO

\# S-S: \# SELECTED STUDIES

refers to the type of study (classification provided in [9]), and iii) Contribution facet: categories or areas where these studies are contributing.

\section{E. Data Extraction and Mapping Process}

To obtain detailed and concise information from the 201 selected studies, a data extraction form is elaborated for each study, which registers the classification of the papers into one of the categories that each facet has. In addition, this form includes their main information such as their title, database, summary, keywords, year of publication, contributions, and advantages; as well as the shortcomings that result in the gaps related to the research problem.

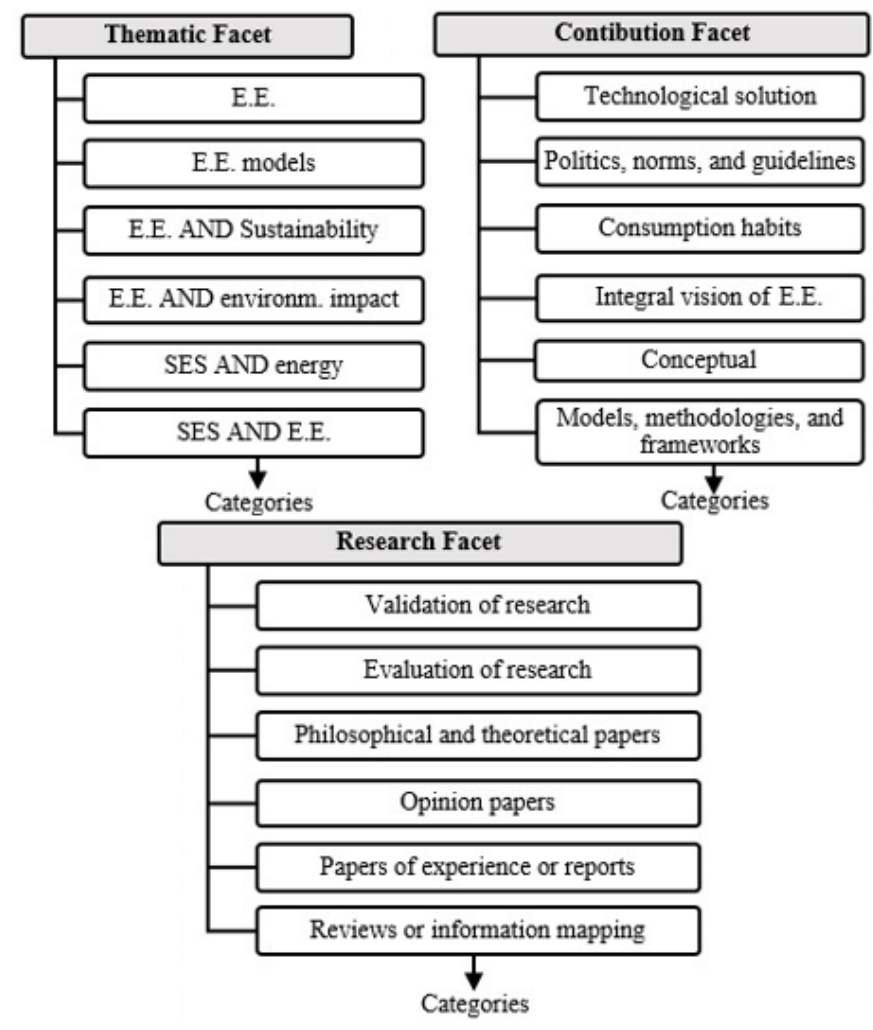

Fig. 2. Classification scheme of studies.

\section{RESULTS}

An x-y bubble scatter diagram with the three facets is used, providing a visual map of the systematic mapping, which informs the frequency of publications in each of the facet categories. This allows for identification of the emphases of previous research, gaps, and possibilities for future studies (See Fig. 3). The size of a bubble is proportional to the number of items that are in the pair of categories that correspond to the bubble's coordinates. The diagram shows: i) in quadrant 1 the relationship between the thematic facet (y axis) and the contribution facet (x-axis), and ii) in quadrant 2 the relationship that exists between the thematic facet (y axis) and the research facet $(\mathrm{x}+\mathrm{axis})$. 

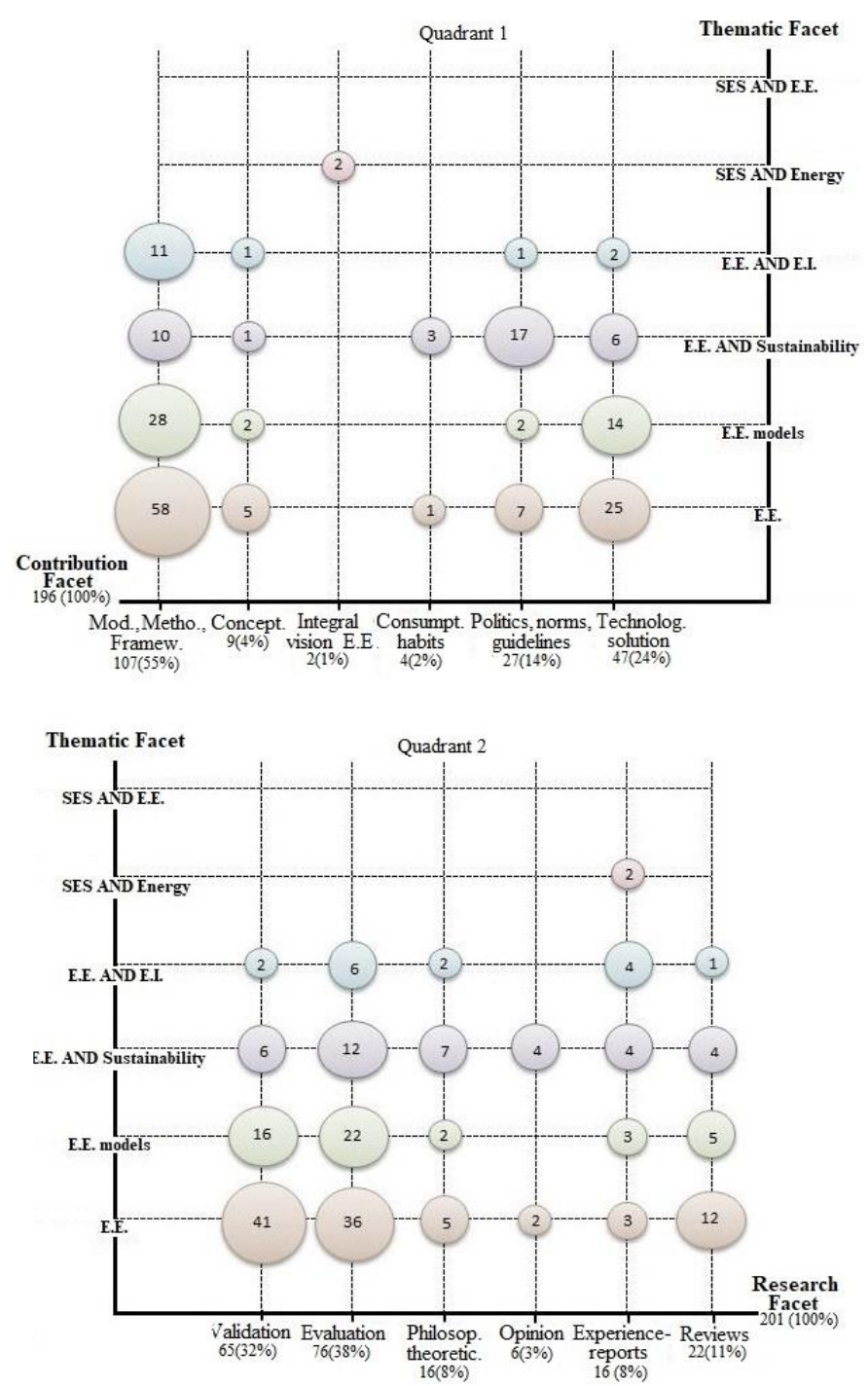

Fig. 3. Visualization diagram of systematic mapping.

In quadrant 1 it is possible to observe that there is, in the first instance, a tendency for scientific texts that address the subject of E.E. (96 documents, equivalent to $49 \%$ ); in the second instance, there are studies on models of E.E. (46 documents, equivalent to 23\%). In both categories, most studies contribute to the development of technological solutions and to the formulation of models, methodologies, or frames of reference. In the third instance, a significant number of documents referring to E.E. and sustainability is seen (37 documents, equivalent to 19\%); these studies mainly contribute to the formulation of policies, norms, and guides, and also to the presentation of models, methodologies, or frames of reference. In the fourth instance, it is possible to see the category of E.E. and environmental impact (15 documents, equivalent to $8 \%$ ), 11 of these works present models, methodologies, or frames of reference. Finally, only 2 studies [10], [11] relate the concepts of SES and energy, contributing to an idea of integral E.E. Meanwhile, no research was found on the subject of SES and E.E.

On the other hand, quadrant 2 shows that a large number of studies were classified in the categories of evaluation (76 papers, showing how the technique is applied in practice) and validation (65 papers, techniques that have not been taken into practice, although they have been validated in the laboratory); representing about $70 \%$ of the studies. Based on the diagram, it is possible to observe that there are few studies that have tried to relate the concepts of SES and Energy, and SES and E.E.

Table 2 shows the most relevant studies for our case study, these works are arranged in relation to the categories of the thematic facet (T.F.). In the same way, a description of the common contents of these studies is presented, and the gaps found.

\begin{tabular}{|c|c|c|c|}
\hline T. F. & Description & Studies & Gaps \\
\hline E.E. & 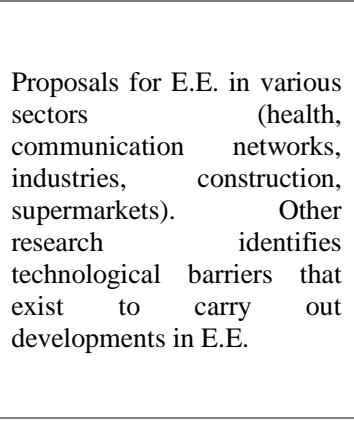 & $\begin{array}{l}{[12],} \\
{[13]} \\
{[14],} \\
{[15]}\end{array}$ & $\begin{array}{l}\text { The solutions } \\
\text { offered by E.E. are } \\
\text { linked to } \\
\text { technological } \\
\text { developments and } \\
\text { the application of } \\
\text { technical } \\
\text { standards. } \\
\text { Socioecological } \\
\text { components are } \\
\text { not integrated into } \\
\text { the proposals for } \\
\text { E.E. }\end{array}$ \\
\hline $\begin{array}{c}\text { E.E. } \\
\text { Models }\end{array}$ & $\begin{array}{l}\text { These show the creation of } \\
\text { models of E.E. to estimate } \\
\text { and/or decrease energy } \\
\text { consumption in industrial } \\
\text { and agricultural processes. } \\
\text { There is a tendency for DEA } \\
\text { models (Data Envelopment } \\
\text { Analysis: methodology } \\
\text { traditionally used for } \\
\text { estimating relative } \\
\text { efficiency). }\end{array}$ & $\begin{array}{c}{[6],} \\
{[16]-} \\
{[19]}\end{array}$ & $\begin{array}{l}\text { Reductionism } \\
\text { when considering } \\
\text { energy as only } \\
\text { electrical energy. } \\
\text { The proposed } \\
\text { solutions are only } \\
\text { based on } \\
\text { technological } \\
\text { improvement. }\end{array}$ \\
\hline $\begin{array}{c}\text { E.E. } \\
\text { AND } \\
\text { Sustain } \\
\text { ability }\end{array}$ & $\begin{array}{l}\text { These define the world } \\
\text { energy sector crisis and } \\
\text { suggest the need to promote } \\
\text { E.E. as an alternative for } \\
\text { sustainable development. } \\
\text { The first } 3 \text { articles suggest } \\
\text { the use of renewable energy } \\
\text { as a solution. The other two } \\
\text { studies focus on energy } \\
\text { management in the } \\
\text { manufacturing sector. }\end{array}$ & $\begin{array}{c}{[20]-} \\
{[22]} \\
{[23],} \\
{[24]}\end{array}$ & $\begin{array}{l}\text { The concept of } \\
\text { sustainability } \\
\text { favors economic } \\
\text { development, over } \\
\text { the conservation of } \\
\text { natural resources. } \\
\text { It is still thought } \\
\text { that the solution to } \\
\text { the energy crisis } \\
\text { will be found } \\
\text { through } \\
\text { technology. }\end{array}$ \\
\hline
\end{tabular}

The common axis of these studies is to show the advantages of E.E. for the E.E. economic system and for the AND reduction of environmental enviro impacts $(\mathrm{CO} 2)$. Each paper describes a scenario of E.E. (e.g. E.E. in residential impact buildings, thermoelectric generators being more energy efficient, and E.E. in the ventilation systems of parking lots).

The two documents propose

SES AND that the topics of energy

Energy management and E.E. must be approached from political,
They reduce the concept of energy down to electricity.

[25] - The environmental

[27] impact analysis is carried out only by measuring $\mathrm{CO} 2$ emissions. interdisciplinary approach, they do the need for an 


$\begin{array}{ll}\text { environmental, social, and } & \text { not show a } \\ \text { technological perspectives. } & \text { methodology or } \\ \text { Interdisciplinary and a } & \text { conceptual } \\ \text { holistic vision must be } & \text { frameworks that } \\ \text { considered in the problems } & \text { allow integrating } \\ \text { linked to energy. } & \text { different areas of } \\ \text { Interestingly, they do not } & \text { knowledge and the } \\ \text { reduce the concept of energy } & \text { possible } \\ \text { down to electricity, they } & \text { relationships } \\ \text { consider all energy sources in } & \text { between them. } \\ \text { their analysis. } & \end{array}$

Taking into account the research question RQ.1 referring to the topics of interest for the scientific community, E.E. represents a broad field of study. The authors have focused their research on the formulation of E.E. models and on the development of technical or technological solutions. In recent years, E.E. has been related to sustainability and environmental impact, seeking to incorporate social, environmental, economic, political, and technological dimensions into the new proposals of E.E.

To answer the question RQ.2 about the main contributions of the studies, it is necessary to note that most of the solutions offered for E.E. are linked to the creation of models, methodologies, frames of reference, and to different technological developments, as evidenced by the bibliographic review presented in [12]. In this work the measures associated with technological components are highlighted, such as: a change to more efficient lighting, installation of controllers in motors and compressors, the use of software to optimize HVAC (Heating, Ventilation and Air Conditioning), installation of timers for light switches, reduction of air ventilation, photocell implementation, etc. Similarly, countries like Germany, Austria, the Netherlands, and the United Kingdom have provided guidelines for good practices and/or technical improvements to improve E.E., but the majority of information is related to technological and organizational applications in the industrial, construction, and transportation sectors [13].

Finally, to answer the question RQ.3 about alternatives that have not been explored in depth and that can provide an understanding and application of E.E. from a sustainable perspective. The result of this systematic mapping opens a window to the possibility that the problems linked to energy must be addressed from a systemic and interdisciplinary paradigm (as proposed by the conceptual framework of the SES). This new approach suggests that E.E. considers the transformations and degradation of energy present in any natural, industrial, agricultural process, etc. In this regard, it is necessary to consider in the analysis of E.E. the different energy sources, such as: fossil fuels, renewable, biomass, electric, nuclear, etc.

This perspective has been gaining strength in countries such as France, where they suggest that the energy issue should be analyzed along with the political, environmental, administrative, social, and technological dimensions [10]. In
Canada, Greenpeace International and the European Council of Renewable Energies (EREC) propose an energy [R] evolution, focused on E.E., renewable energies, and based on respect for the limits of natural resources [11]. The foregoing is proposed as an alternative to sustainability, with the objective being that society should not consume more than what the systems provide (not exceed its carrying capacity) [28].

Although [10] and [11] are focused on the need to approach the problem holistically they do not present an interdisciplinary methodology that allows for the complexity of the environmental and energetic problems to be adequately addressed. These studies are only focused on reconciling the relationship between man and nature, but they leave out the interactions, processes, and limitations that societies harbor in their intrinsic structure.

\section{DISCUSSION}

Modern society faces an unprecedented energy emergency, due to the depletion of energy resources, the transition into new energy models, and the exponential growth of the economy based on the consumption of natural resources. In this regard, large institutions such as: The International Energy Agency (IEA), the European Commission (EC), the Intergovernmental Panel on Climate Change (GIEC) and the World Energy Council, estimate that E.E. (considering different energy sources) is an essential tool for progress towards a low carbon economy [10], [11]. Colombia cannot be indifferent to these transformations and must propose a comprehensive proposal on E.E, which executes environmental sustainability actions. To this end, it is necessary to approach the problem from a systemic, interdisciplinary paradigm that integrates principles that reduce the degradation of energy in systems, such as: conserving resources for future use, a rethinking of the resource consumption model, a social and political structure that demands a sense of responsibility in consumption, a cessation of the belief that there is an availability of immense wealth and inexhaustible resources that can be incorporated into production systems, and a rupture of the mentality of appropriation of resources without limits (water, mining, soils). For these reasons, the following are the bases for constructing an alternative proposal for E.E.

\section{A. Basis for an Alternative Vision of E.E. in Colombia}

The concept of efficiency is commonly used in the policy, planning, and commercial approaches of the development model proposed by a country. In the case of Colombia, documents such as: "Basis of the National Development Plan" [29] and "Report to the Congress from Juan Manuel Santos, 2014" [30], make use of this concept. E.E. is promoted as a tool that will contribute to the sustainable development and conservation of the environment [31], [32]. However, government plans continue to promote activities that boost economic growth based on intensive consumption of natural resources (especially non-renewable resources), under the 
mistaken idea that nature is an infinite base for the current economic model.

There are three main disciplines that have addressed in their studies the concept of efficiency: thermodynamics, economics, and ecology. Thermodynamics indicates that efficiency is the ratio between useful output energy and input energy in a system [33]. For economy, efficiency is a multidimensional concept, but it is possible to group it in two theoretical bases: the theory of production and the theory of well-being [34]. And for ecology, efficiency can be studied from three postulates: i) efficiency between trophic levels [35], ii) energy transformation, and iii) maximum power principle [36].

From this standpoint, in order to understand a general scenario of E.E. (different energy sources), an adaptation of the three-level conceptual framework presented in [37] was made (Fig. 4). Level I is the efficiency space, where a triangulation and complementarity of the concept of efficiency from the disciplines: thermodynamics, economics, and ecology, allows for an interdisciplinary and comprehensive approach to the social-ecological interactions that are present in any context (flows of Energy, Matter, Information). The level II decision space, seeks the application of criteria with the aim of improving the efficiency in the system. Decision making is an iterative process, recognizing forward movements to analyze the services and limitations of the biophysical space and going backwards to evaluate the probable results of decision making efficiency. Level III is the biophysical space (biosphere), which configures and ultimately frames society.

On the basis of the proposed conceptual framework, we propose the following concept: "energy efficiency is the foundation of equity and sustainability where the ecological limitations of natural systems and the demands on environmental services of society are valued, taking into account decisions, the opportunity, and the energy requirements for an end, channeling most of the available energy into the production of goods and/or services and avoiding the degradation of energy into possible pollutants and waste" [38].

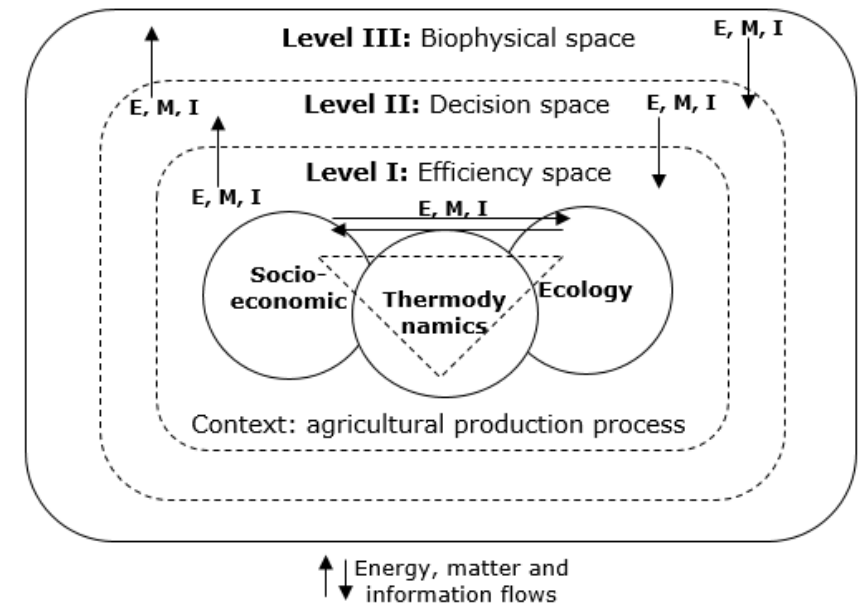

Fig. 4. Framework of three levels (spatial) on the concept of energy efficiency

Similarly, it is necessary to consider that the systems are structured hierarchically [39]. Every system is part of a larger system that contains it, and in turn is made up of several subsystems. For this reason, the functional processes of a system must be analyzed at different spatial and temporal scales (see Fig. 5). For example, a relevant form of intervention for the communities towards their local environment are their agricultural production processes. The energy efficiency and sustainability of these agricultural systems affect a larger system such as the region and more globally a country. In the same way, the country analyzed as a major system is responsible for the different energy, economic, environmental, and agricultural policies that determine the functionality of smaller systems. However, the scale of the world economy determines the development of the countries, and finally, the biosphere is what ultimately frames society, since it establishes the limits of the physical environment and the finite condition of nature.

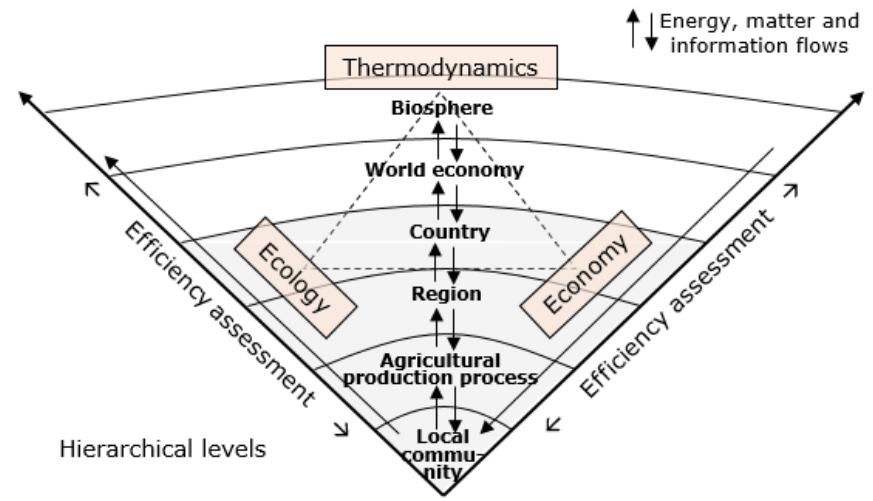

Fig. 5. Hierarchical levels in which energy efficiency can be analysed.

The metabolism of a society, leads to multiple interconnections at the regional level, through the transport of materials and supplies (energy flows). As a result, what happens in one system has repercussions in another [40]. An important consequence of this hierarchical organization is that the components or subsystems are combined producing a larger functional whole, in this way new properties emerge 
that are not present in lower levels. This complexity of interactions has generally been ignored and consequently, many environmental effects resulting from "insignificant" activities carried out in small subsystems, when all added up, can have regional or global impacts, such as water and air pollution [41]. The foregoing, indicates how environmental problems have transcended from a local to a global scale [42], requiring alternatives to understand the problems from a systemic viewpoint.

\section{CONCLUSIONS}

The main objective of this study is to develop a systematic mapping of the literature related to Energy Efficiency (E.E.). It is important to highlight that this subject is quite broad and the documentary analysis is approached from the posing of 3 research questions, which allows this topic to be studied in a systemic way.

The areas of greatest interest to the scientific community in regard to E.E. are the E.E. models, and E.E. being applied mainly to the industrial, transportation, and construction contexts. Recently issues such as sustainability and environmental impact have been connected to E.E., using it as a tool that will allow for the sustainable development of society. The main contributions of the studies analyzed in the mapping are directed toward the formulation of models, methodologies, and frames of reference for E.E., along with the development of technical or technological solutions. The research they provide conceptually is scarce, as is their approach to policies, norms, and guidelines.

Based on the systematic mapping carried out, one of the poorly explored alternatives on the subject of E.E. from a sustainable perspective, is the conceptualization of energy problems from a systemic and interdisciplinary approach, which allows for the assessment of all types of energy and the analysis of the processes of transformation and degradation of energy in a given system. Based on this identified gap, the foundations for an alternative vision of E.E. are presented, where a concept of E.E. is proposed, as a pillar of environmental sustainability. In addition, the evaluation of E.E. from a systemic perspective is presented. For future work, the construction of a conceptual framework of E.E. directed toward agricultural production chains is expected, given the great importance of this sector in the Colombian context.

\section{ACKNOWLEDGMENT}

Authors wish to express their sincere gratitude to Mitchell Tijerina of all his support in the writing process of this document.

\section{REFERENCES}

P. Malanima, "Energy in History," in The Basic Environmental History, vol. 4, Springer International Publishing, 2014, pp. 1-29. DOI: https://doi.org/10.1007/978-3-319-09180-8_1

[2] G. P. Beretta, "World Energy Consumption and Resources: An
Outlook For The Rest Of The Century," Int. J. Environ. Technol. Manag., vol. 7, no. 1/2, pp. 99-112, 2007. DOI: https://doi.org/10.1504/IJETM.2007.013239

[3] C. Bonneuil, "Tous responsables?," Le Monde Dipl., no. 11, p. 16a16a, 2015.

[4] D. W. Pearce and R. K. Turner, Economics of natural resources and the environment. JHU Press, 1990.

[5] European Commission, "Efficacité Energétique dans le secteur industriel," 2010

[6] M. G. Patterson, "What is energy efficiency?: Concepts, indicators and methodological issues," Energy Policy, vol. 24, no. 5, pp. 377390, 1996. DOI: 10.1016/0301-4215(96)00017-1

[7] R. Kümmel, "Energy, creativity and sustainable growth," Our Fragile World - Challenges Oppor. Sustain. Dev. Oxford EOLSS, p. 409, 2001.

[8] K. Petersen, R. Feldt, S. Mujtaba, and M. Mattsson, "Systematic Mapping Studies in Software Engineering.," in EASE, 2008, vol. 8, pp. $68-77$.

[9] R. Wieringa, N. Maiden, N. Mead, and C. Rolland, "Requirements engineering paper classification and evaluation criteria: a proposal and a discussion," Requir. Eng., vol. 11, no. 1, pp. 102-107, 2006. DOI: 10.1007/s00766-005-0021-6

[10] A. De Béthencourt and J. Chorin, "Efficacité énergétique: un gisement d'économies, un objectif prioritaire," Journaux Off. Fr., no. Conseil économique, social et environnemental, 2013.

[11] European Renewable Energy Council and Greenpeace International, “[ r ] évolution énergétique," 2010. DOI: 10.4324/9781849775144

[12] A. Trianni, E. Cagno, and A. De Donatis, "A framework to characterize energy efficiency measures," Appl. Energy, vol. 118, pp. 207-220, 2014. DOI: 10.1016/j.apenergy.2013.12.042

[13] European Commission, "Efficacité énergétique," 2009.

[14] E. Cagno, E. Worrell, A. Trianni, and G. Pugliese, "A novel approach for barriers to industrial energy efficiency," Renew. Sustain. Energy Rev., vol. 19, pp. 290-308, 2013. DOI: 10.1016/j.rser.2012.11.007

[15] A. Trianni, E. Cagno, P. Thollander, and S. Backlund, "Barriers to industrial energy efficiency in foundries: a European comparison," J. Clean. Prod., vol. 40, pp. 161-176, 2013. 10.1016/j.jclepro.2012.08.040

[16] N. Dongxiao, L. Xin, and Q. Huanhuan, "Empirical analysis on Shanxi electric energy efficiency by DEA model," in Cross Strait Quad-Regional Radio Science and Wireless Technology Conference (CSQRWC), 2011, 2011, vol. 2, pp. 1184-1187. DOI: 10.1109/CSQRWC.2011.6037172

[17] S. K. Lee, G. Mogi, S. C. Shin, and J. W. Kim, "An AHP/DEA hybrid model for measuring the relative efficiency of energy efficiency technologies," in Industrial Engineering and Engineering Management, 2007 IEEE International Conference on, 2007, pp. 55-59. DOI: 10.1109/IEEM.2007.4419150

[18] G. Vlontzos, S. Niavis, and B. Manos, "A DEA approach for estimating the agricultural energy and environmental efficiency of EU countries," Renew. Sustain. Energy Rev., vol. 40, pp. 91-96, 2014. DOI: 10.1016/j.rser.2014.07.153

[19] Q. Wang, Z. Zhao, P. Zhou, and D. Zhou, "Energy efficiency and production technology heterogeneity in China: a meta-frontier DEA approach," Econ. Model., vol. 35, pp. 283-289, 2013. DOI: 10.1016/j.econmod.2013.07.017

[20] M. Dolinsky, "Sustainable systems-game theory as a tool for preserving energy resources," Energy. Sustain. Soc., vol. 5, no. 1, p. 6, 2015. DOI: $10.1186 / \mathrm{s} 13705-014-0030-8$

[21] M. K. Deshmukh and S. S. Deshmukh, "Modeling of hybrid renewable energy systems," Renew. Sustain. Energy Rev., vol. 12, no. 1, pp. 235-249, 2008. DOI: 10.1016/j.rser.2006.07.011

[22] P. Bajpai and V. Dash, "Hybrid renewable energy systems for power generation in stand-alone applications: a review," Renew. Sustain. Energy Rev., vol. 16, no. 5, pp. 2926-2939, 2012. DOI: 10.1016/j.rser.2012.02.009

[23] C. Herrmann, C. Schmidt, D. Kurle, S. Blume, and S. Thiede, "Sustainability in Manufacturing and Factories of the Future," Int. J. Precis. Eng. Manuf. Technol., vol. 1, no. 4, pp. 283-292, 2014. DOI: $10.1007 / \mathrm{s} 40684-014-0034-\mathrm{z}$

[24] A. Trianni, E. Cagno, and S. Farné, "Barriers, drivers and decisionmaking process for industrial energy efficiency: a broad study among manufacturing small and medium-sized enterprises," Appl. Energy, vol. 162, pp. 1537-1551, 2016. DOI: 
10.1016/j.apenergy.2015.02.078

T. Gil-Lopez, A. Sanchez-Sanchez, and C. Gimenez-Molina, "Energy, environmental and economic analysis of the ventilation system of enclosed parking garages: Discrepancies with the current regulations," Appl. Energy, vol. 113, pp. 622-630, 2014. DOI: 10.1016/j.apenergy.2013.08.012

[26] A. Patyk, "Thermoelectric generators for efficiency improvement of power generation by motor generators-environmental and economic perspectives," Appl. Energy, vol. 102, pp. 1448-1457, 2013. DOI: 10.1016/j.apenergy.2012.09.007

[27] J.-K. Choi, D. Morrison, K. P. Hallinan, and R. J. Brecha, "Economic and environmental impacts of community-based residential building energy efficiency investment," Energy, vol. 78, pp. 877-886, 2014. DOI: 10.1016/j.energy.2014.10.082

[28] K. Arrow et al., "Economic growth, carrying capacity, and the environment," Ecol. Econ., vol. 268, pp. 520-521, 1995. DOI: 10.1126/science.268.5210.520

[29] Departamento Nacional de Planeación, "Bases del Plan Nacional de Desarrollo 2014-2018," 2014.

[30] -DNP- Departamento Nacional de Planeación and -DSEPPDirección de Seguimiento y Evaluación de Políticas Públicas, "INFORME AL CONGRESO JUAN MANUEL SANTOS 2014," 2014.

[31] J. Harlow, A. Golub, and B. Allenby, "A review of utopian themes in sustainable development discourse," Sustain. Dev., vol. 21, no. 4, pp. 270-280, 2013. DOI: 10.1002/sd.522

[32] D. Ruiz, J. P. Martínez, and A. Figueroa, "Importancia del 'efecto rebote' o paradoja de Jevons en el diseño de la política ambiental," Rev. Ing. Univ. Medellín, vol. 14, no. 27, 2015. DOI: 10.22395/rium.v14n27a3

[33] D. Kondepudi and I. Prigogine, Modern thermodynamics: from heat engines to dissipative structures. John Wiley \& Sons, 2014. DOI: $10.1002 / 9781118698723$

[34] H. Leibenstein, "Allocative efficiency vs.' X-efficiency,” Am. Econ. Rev., vol. 56, no. 3, pp. 392-415, 1966.

[35] E. P. Odum and G. W. Barrett, Fundamentals of ecology, vol. 3. Philadelphia: Saunders, 1971.

[36] H. T. Odum, Environmental accounting: emergy and environmental decision making. Wiley, 1996.

[37] N. Jollands, "Concepts of efficiency in ecological economics: Sisyphus and the decision maker," Ecol. Econ., vol. 56, no. 3, pp. 359-372, 2006 DOI: 10.1016/j.ecolecon.2005.09.014

[38] C. M. Rodríguez, C. F. R. Rodas, J. C. C. Muñoz, and A. F. Casas, "A multi-criteria approach for comparison of environmental assessment methods in the analysis of the energy efficiency in agricultural production systems," J. Clean. Prod., vol. 228, pp. 1464-1471, 2019. DOI: $10.1016 /$ j.jclepro.2019.04.388

[39] O. Ossa and C. Alberto, Teoría general de sistemas: conceptos y aplicaciones. Universidad Tecnológica de Pereira, 2016.

[40] M. G. Turner, R. H. Gardner, and R. V O'neill, Landscape ecology in theory and practice, vol. 401. Springer, 2001.

[41] M. Giampietro, "Economic growth, human disturbance to ecological systems, and sustainability,” Ecosyst. WORLD, pp. 723-746, 1999.

[42] T. Clayton and N. J. Radcliffe, Sustainability: a systems approach. Routledge, 2015.

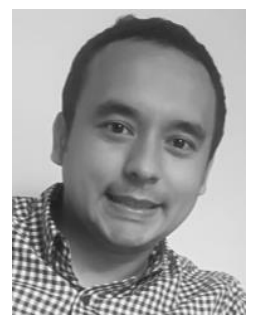

Cristian Méndez-Rodríguez received the B.S. degree in industrial automatic engineering from the University of Cauca, Cauca, Colombia, in 2010, the M.S. degree in automatic and robotic from the École Centrale de Nantes (ECN), France, in 2013. $\mathrm{He}$ is currently Ph.D. scholarship holder of Colciencias in Environmental Science at University of Cauca. His research interest focus on energy efficiency, sustainability and environment.

ORCID: https://orcid.org/0000-0002-4489-2712

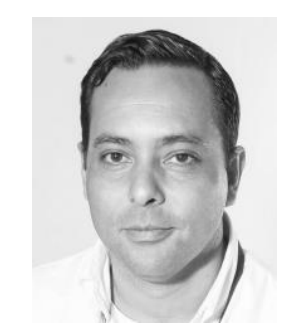

Carlos F. Rengifo-Rodas received the B.S. and M.S. degrees in electric engineering from the University of Valle, Valle, Colombia, in 1996 and 2000, respectively, and the Ph.D. degree in Automatic from the École Centrale de Nantes (ECN), France, in 2010. He is currently a Full Professor with the Electronics, Instrumentation and Control Department, University of Cauca. His research interest focus on process control, control and robotics.

ORCID: https://orcid.org/0000-0002-0601-3481

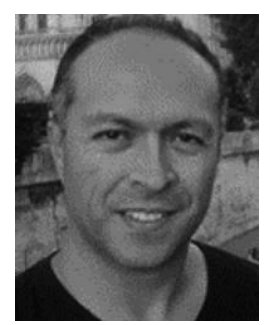

Juan Carlos Corrales-Muñoz received the B.S. and M.S. degrees in telematics engineering from the University of Cauca, Cauca, Colombia, in 1999 and 2004, respectively, and the Ph.D. degree in computer science from the University of Versailles Saint-Quentin-en-Yvelines, France, in 2008. He is currently a Full Professor with the Electronics and Telecommunications Department, University of Cauca, where he is also the Director of the Telematics Engineering Group. His research interests focus on service composition, data analysis, and remote sensing. He promotes and supervises research.

ORCID: https://orcid.org/0000-0002-5608-9097

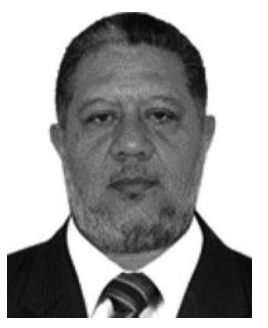

Apolinar Figueroa-Casas received the B.S degree in biology from the University of Cauca, Colombia, in 1982, the M.S. degree in ecology from the University of Barcelona, Spain, in 1986, and the Ph.D. in biological sciences from the University of Valencia, Spain, in 1999.

He has been a Visiting Professor at the National University of Rosario, Argentina, University of Valle, Colombia, Technological University of Pereira, Colombia, and Polytechnic University of Catalonia, Spain. He is currently a Full Professor at the Biology Department of the University of Cauca, Cauca, Colombia. He is the Founder and Director of the Environmental Studies Group, University of Cauca. He is also the Founder of the Ph.D. program in Environmental Studies of the University of Cauca. His research interest include Ecology of Andean systems, Ecosistemology, anthropic ecosystem processes, and Remote Sensing. He has led projects in the framework of sustainability environmental financed by the Colombian government and international cooperation.

ORCID: https://orcid.org/0000-0003-3586-8187 